\title{
Pengaruh Perbandingan Tepung Singkong (Manihot esculenta Cranz) Dan Puree Wortel (Daucus carota L) Terhadap Karakteristik Kue stik
}

\section{The Effect of Cassava Flour (Manihot esculenta Cranz) And Puree of Carrot (Daucus carota L) Ratio on The Characteristic of Stick Cake}

\author{
I Made Askara Diputra ${ }^{1}$, Putu Timur Ina ${ }^{1 *}$, Gusti Ayu Kadek Diah Puspawati ${ }^{1}$ \\ Program Studi Teknologi Pangan, Fakultas Teknologi Pertanian, \\ Universitas Udayana, Kampus Bukit Jimbaran, Badung-Bali \\ Penulis korespondensi: P.T.Ina, Email: timurina@unud.ac.id
}

\begin{abstract}
This research aims to identify the effect of cassava flour and puree of carrot ratio on the characteristic of stick cake and to find out the ratio of cassava flour and puree of carrot to produce stick cake with the best characteristics. This research used a completely randomized design with the treatment ratio of cassava flour and puree of carrot consisted of three levels such as 90\%:10\%,80\%:20\%, and 70\%:30\%. The treatment was repeated 3 times so that it is obtained 15 experimental units. The parameters observed were water content, ash content, crude fiber content, beta carotene content and the sensory characteristics (color, texture, aroma, taste and overall acceptability) using hedonic tests. The data were analyzed by analysis of variance and the treatment had a significant effect, followed by the Duncan Multiple Range Test. The results showed that the ratio of cassava flour and puree of carrot had a significant effect on the water content, the ash content, the crude fiber content, beta carotene content but did not significantly affect the sensory characteristics. Ratio of $70 \%$ cassava flour and $30 \%$ puree of carrot had the best characteristics that were water content of $1.96 \%$, ash content of $2.01 \%$, crude fiber content of $2.29 \%$, beta carotene content of 6.77 $\mathrm{mg} / 100 \mathrm{~g}$, color, texture, aroma, taste, and overall acceptance was liked.
\end{abstract}

Keywords : cassava flour, puree of carrot, stick cake

\section{PENDAHULUAN}

Kue stik merupakan salah satu makanan ringan atau jenis kue kering yang diminati oleh masyarakat sebagai cemilan sehari-hari mulai dari anak-anak, remaja hingga orang dewasa (Habeahan, 2018). Kue stik sangat mudah dijumpa di pasar tradisional maupun supermarket karena harganya yang murah dan cocok untuk semua kalangan. Kue stik memiliki bentuk memanjang seukuran pensil yang mempunyai rasa gurih serta bertekstur renyah (Habeahan, 2018). Pembuatan kue stik pada umumnya menggunakan bahan dasar terigu, hal ini menyumbang peningkatkan penggunaan terigu pada produk pangan di Indonesia. Anon. (2019) melaporkan konsumsi terigu nasional pada akhir tahun 2018 mencapai 6,52 juta ton dan pertumbuhan konsumsi terigu selama 10 tahun terakhir rata-rata mencapai $5 \%$ per tahun. Jumlah ini akan terus berkembang seiring dengan pertumbuhan penduduk Indonesia.

Terigu merupakan tepung gandum yang dihasilkan dari proses penggilingan biji gandum (Yanuarti dan Afsari, 2016). Gandum tidak dapat dihasilkan di Indonesia sehingga merupakan barang impor. Anon. (2018) melaporkan volume import gandum 
Indonesia pada tahun 2017 mencapai angka 11,48 juta ton. Berdasarkan hal tersebut diperlukan pengurangan penggunaan gandum sebagai bahan utama dalam pengolahan pangan di Indonesia dengan cara mengoptimalkan pemanfaatan bahan pangan lokal agar dapat memperkuat ketahanan pangan di Indonesia.

Saat ini kue stik sudah cukup banyak dimodifikasi terutama penggantian bahan baku yaitu terigu dengan bahan pangan lokal seperti umbi-umbian. Habeahan (2018) melaporkan pengolahan kue stik dengan tepung ubi jalar orange dan tepung kelor, kue stik yang dihasilkan mengalami peningkatan kandungan kalsium dan pro vitamin A. Sari dan Bahar (2014) melaporkan pengolahan kue stik dengan substitusi mocaf dan puree wortel berpengaruh terhadap warna, kerenyahan dan kandungan gizi pada kue stik. Penggunaan mocaf cukup mempersulit dalam pembuataan kue stik karena harga mocaf tergolong mahal dan perlu waktu lebih untuk membuat mocaf itu sendiri. Upaya untuk meminimalkan biaya bahan pokok dalam pembuatan kue stik dapat menggunakan tepung singkong.

Tepung singkong dari bahan baku singkong kuning mengandung protein, lemak, karbohidrat, kalsium, fosfor, besi, serta pro vitamin A dalam bentuk beta karoten yang memberikan warna kuning oranye pada singkong (Widowati dan Damardjati, 2001). Pati adalah salah satu kandungan pada terigu yang membuat kue stik renyah (Salim, 2011). Singkong mengandung pati yang cukup tinggi yaitu sebesar 24\% sehingga kandungan tersebut memungkinkan mengganti penggunaan terigu sebagai bahan dasar pembuatan kue stik. Tepung singkong mudah dibuat dibandingkan dengan mocaf karena hanya perlu dilakukan pengeringan dan penghalusan sehingga biaya dalam pembuatan tepung singkong lebih murah dan praktis dibandingkan dengan pembuatan mocaf. Pembuatan kue stik dapat ditambahkan bahan pangan lain seperti wortel untuk meningkatkan kandungan gizi dalam kue stik tersebut.

Wortel merupakan sayuran yang memiliki kandungan beta karoten (pro vitamin A) yang cukup tinggi sehingga dapat membantu mencegah penyakit rabun senja (Astarina, 2010). Wortel kurang digemari oleh anak-anak karena rasa nya yang kurang disukai dan bau langu yang dihasilkan. Sebagian besar masyarakat Indonesia selama ini belum memanfaatkan wortel secara optimal. Wortel biasanya hanya dimanfaatkan dalam pengolahan menu sayuran seperti sup, urap dan capcay. Pemanfaatan komoditi wortel saat ini masih terbatas, maka perlu dilakukan pengolahan lain agar penggunaan wortel menjadi lebih luas. Pengolahan wortel menjadi puree merupakan salah satu hal yang dapat dilakukan untuk dijadikan tambahan bahan pada produk pangan yang sudah umum 
berada di pasaran. Pengolahan wortel menjadi puree dapat mempermudah pencampuran bahan ke dalam adonan kue stik sehingga menghasilkan adonan yang homogen. Penambahan puree wortel dalam produk seperti stik dapat mempengaruhi karakteristiknya. Sari dan Bahar (2014) melaporkan penambahan puree wortel pada pembuatan stik dengan substitusi mocaf dapat mempengaruhi warna, kerenyahan dan kandungan gizinya. Berdasarkan hal tersebut dilakukan penelitian dengan tujuan menentukan pengaruh perbandingan tepung singkong dan puree wortel terhadap karakteristik kue stik dan menentukan perbandingan tepung singkong dan puree wortel yang tepat untuk menghasilkan kue stik dengan karakteristik terbaik.

\section{METODE PENELITIAN}

\section{Bahan dan Alat}

Bahan yang digunakan dalam penelitian ini terdiri dari bahan baku, bahan tambahan, dan bahan kimia. Bahan baku terdiri dari wortel lokal segar yang berasal dari Tabanan berwana kuning oranye dan singkong kuning yang berasal dari Buleleng serta terigu (merek kunci biru). Bahan tambahan terdiri dari bawang merah, bawang putih, margarin (merek blueband), garam (dolpin), dan telur yang diperoleh di toko UD Fenny dan air. Bahan kimia yang digunakan pada penelitian ini adalah aquades, $\mathrm{NaOH}$, alkohol 95\%, $\mathrm{H}_{2} \mathrm{SO}_{4}$, $\mathrm{Na}_{2} \mathrm{SO}_{4}$ dan petroleum benzine.
Alat yang digunakan dalam melaksanakan penelitian ini antara lain pisau, oven (Cole-Parmer), baskom, blender (Philip's), ayakan 60 mesh, panci, saringan, loyang, pasta maker, parutan, meja, lumpang, cawan, cawan porselin, timbangan analitik (Simadzu ATY224), pinset, deksikator, muffle purnance (Daihan), sentrifugasi (Danamon IEC), erlenmeyer, waterbath, batang pengaduk, pipet ukur, termometer, gelas ukur, piala gelas, soxhlet (Behrotest), kertas saring, corong, pipet tetes, labu ukur, tip, vortex (Maxi mix II), spektrofotometer (Genesys 10S Uv-Vis), botol kaca, pipet mikro, aluminium foil.

\section{Rancangan Percobaan}

Penelitian ini menggunakan Rancangan Acak Lengkap (RAL) dengan perlakuan perbandingan tepung singkong dan puree wortel yang terdiri dari: $\mathrm{P} 1=90 \%$ $: 10 \%, \mathrm{P} 2=80 \%: 20 \%$ dan $\mathrm{P} 3=70 \%: 30 \%$. Masing-masing perlakuan diulang sebanyak 5 kali sehingga diperoleh 15 unit percobaan. Data yang diperoleh dianalisis dengan sidik ragam dan apabila perlakuan berpengaruh terhadap parameter yang diamati maka dilanjutkan dengan uji Duncan Multiple Range Test (Gomez dan Gomez, 1995).

\section{Parameter yang Diamati}

Parameter yang diamati pada penelitian ini adalah kadar air dianalisis dengan metode gravimetri, kadar abu dianalsis dengan metode gravimetri, kadar serat kasar dianalisis dengan metode gravimetri (AOAC, 2006), kadar $\beta$-karoten 
dianalisis dengan metode spektrofotometri (Apriyantono, 1989) dan sifat sensoris (warna, rasa, tekstur, aroma, dan penerimaaan keseluruhan) dengan uji hedonik (Soekarto,1985).

\section{Pelaksanaan Penelitian}

Pelaksanaan penelitian meliputi beberapa tahap sebagai berikut.

\section{Proses Pembuatan Tepung Singkong}

Umbi singkong disortasi dan dikupas.

Singkong kemudian dicuci dengan menggunakan air mengalir dan direndam dalam air selama 30 menit dan ditiriskan. Singkong diiris tipis dengan ketebalan $1 \mathrm{~mm}$ dan kemudian dikeringan dengan oven pada suhu $60^{\circ} \mathrm{C}$ selama $12 \mathrm{jam}$, dengan ciri -ciri mudah dipatahkan dan digiling hingga halus dan diayak dengan ayakan 60 mesh.

\section{Proses Pembuatan Puree Wortel}

Wortel segar disortasi, dicuci dengan air bersih dan dikupas. Wortel kemudian diparut dan diblansir dengan steam water blanching pada suhu $75^{\circ} \mathrm{C}$ selama 3 menit. Parutan wortel kemudian diblender hingga halus sehingga diperoleh puree wortel.

\section{Proses Pembuatan Kue stik}

Bahan yang digunakan kemudian ditimbang sesuai dengan formula. Formula pembuatan kue stik untuk perbandingan tepung singkong dan puree wortel dapat dilihat pada Tabel 1. Bahan kering (tepung singkong, terigu dan garam) dicampur dan diaduk hingga merata. Masukkan bahan basah (puree wortel, telur, margarin, bawang merah dan bawang putih halus serta air sesuai formula) dan diuleni hingga adonan menjadi kalis. Adonan yang telah kalis dipipihkan menjadi lembaran dengan ketebalan $1 \mathrm{~mm}$ menggunakan pasta maker. Lembaran dicetak dengan pasta maker dan dipotong dengan panjang $10 \mathrm{~cm}$. Hasil cetakan adonan kue stik digoreng hingga tercelup ke dalam minyak panas pada suhu $170^{\circ} \mathrm{C}$ selama 3 menit.

Tabel 1. Formula kue stik bawang perbandingan tepung singkong dan puree wortel

\begin{tabular}{lccc}
\hline \multirow{2}{*}{ Komposisi Bahan (\%) } & \multicolumn{3}{c}{ Perlakuan } \\
\cline { 2 - 4 } & P1 & P2 & P3 \\
\hline Tepung Singkong & 90 & 80 & 70 \\
Puree Wortel & 10 & 20 & 30 \\
Terigu & 50 & 50 & 50 \\
Margarin & 5 & 5 & 5 \\
Telur & 30 & 30 & 30 \\
Bawang Merah & 3 & 3 & 3 \\
Bawang Putih & 3 & 3 & 3 \\
Garam & 2 & 2 & 2 \\
Air & 30 & 30 & 30 \\
\hline
\end{tabular}

Keterangan: Persentase diatas berdasarkan jumlah tepung singkong dan puree wortel (100 gram) 


\section{HASIL DAN PEMBAHASAN}

Nilai rata-rata kadar air, kadar abu, kadar serat kasar dan kadar betakaroten dari bahan baku tepung singkong dan puree wortel dapat dilihat pada Tabel 2. Nilai rata-rata kadar air, kadar abu, kadar serat kasar dan kadar beta karoten pada kue stik perbandingan tepung singkong dan puree wortel dapat dilihat pada Tabel 3.

Tabel 2. Nilai rata-rata kadar air, kadar abu, kadar serat kasar dan kadar beta karoten dari bahan baku tepung singkong dan puree wortel.

\begin{tabular}{lcc}
\hline \multicolumn{1}{c}{ Komponen } & Tepung singkong & Puree wortel \\
\hline Kadar Air (\% bk) & 8,37 & 769,63 \\
Kadar Abu (\% bk) & 0,88 & 8,86 \\
Kadar Serat (\% bk) & 0,18 & 16,35 \\
Kadar $\beta$-karoten $(\mathrm{mg} / 100 \mathrm{~g})$ & 0,16 & 13,30 \\
\hline
\end{tabular}

Tabel 3. Nilai rata-rata kadar air, kadar abu, kadar serat kasar dan kadar beta karoten pada kue stik perbandingan tepung singkong dan puree wortel

\begin{tabular}{ccccc}
\hline $\begin{array}{c}\text { Tepung singkong: } \\
\text { Puree wortel }\end{array}$ & $\begin{array}{c}\text { Kadar Air } \\
(\%)\end{array}$ & $\begin{array}{c}\text { Kadar Abu } \\
(\%)\end{array}$ & $\begin{array}{c}\text { Kadar Serat Kasar } \\
(\%)\end{array}$ & $\begin{array}{c}\text { Kadar } \beta \text {-karoten } \\
(\mathrm{mg} / 100 \mathrm{~g})\end{array}$ \\
\hline P1 $(90 \%: 10 \%)$ & $1,38 \pm 0,11 \mathrm{c}$ & $1,41 \pm 0,03 \mathrm{c}$ & $1,10 \pm 0,09 \mathrm{c}$ & $3,27 \pm 0,11 \mathrm{c}$ \\
P2 $(80 \%: 20 \%)$ & $1,68 \pm 0,05 \mathrm{~b}$ & $1,75 \pm 0,05 \mathrm{~b}$ & $1,37 \pm 0,09 \mathrm{~b}$ & $4,30 \pm 0,23 \mathrm{~b}$ \\
P3 (70\%:30\%) & $1,96 \pm 0,06 \mathrm{a}$ & $2,01 \pm 0,05 \mathrm{a}$ & $2,29 \pm 0,27 \mathrm{a}$ & $6,77 \pm 0,24 \mathrm{a}$
\end{tabular}

Keterangan: Huruf yang sama dibelakang nilai rata-rata pada kolom yang sama menunjukkan berbeda tidak nyata $(\mathrm{P}>0,05)$.

\section{Kadar Air}

Hasil sidik ragam menunjukkan bahwa perbandingan tepung singkong dan puree wortel berpengaruh sangat nyata $(\mathrm{p}<0,05)$ terhadap kadar air kue stik. Tabel 3 menunjukkan nilai rata-rata kadar air pada kue stik perbandingan tepung singkong dan puree wortel berkisar antara $1,38 \%-1,96 \%$. Nilai rata-rata kadar air tertinggi terdapat pada $\mathrm{P} 3$ yaitu $1.96 \%$ dan nilai rata-rata kadar air terendah terdapat pada P1 yaitu 1,38\%. Hal ini menunjukkan bahwa semakin banyak penambahan puree wortel, maka kadar air kue stik semakin meningkat. Hal ini disebabkan kadar air pada puree wortel lebih tinggi dibandingkan dengan kadar air tepung singkong. Tabel 2 menunjukkan kadar air puree wortel sebesar 769,63\% bk sedangkan kadar air tepung singkong sebesar 8,37\% bk. Menurut SNI 01-2973-1992 tentang syarat mutu kue kering, kue stik dengan perbandingan tepung singkong dan puree wortel ini telah memenuhi standar yaitu maksimal 4\%. Kadar air pada kue stik memiliki peran penting dalam kerenyahan tekstur kue stik tersebut. Semakin rendah nilai kadar air pada kue stik semakin baik tekstur yang di hasilkan. Rendahnya kadar 
air pada kue stik dapat menghambat pertumbuhan mikroba sehingga terjadinya kontaminasi mikroba sangat rendah.

\section{Kadar Abu}

Hasil sidik ragam menunjukkan bahwa perbandingan tepung singkong dan puree wortel berpengaruh nyata $(p<0,05)$ terhadap kadar abu kue stik. Tabel 3 menunjukkan nilai rata-rata kadar abu pada kue stik perbandingan tepung singkong dan puree wortel berkisar antara 1,41\% - 2,01\%. Nilai rata-rata kadar abu terendah terdapat pada $\mathrm{P} 1$ yaitu $1,41 \%$ dan nilai rata-rata kadar abu tertinggi terdapat pada P3 yaitu 2,01\%. Kadar abu kue stik cenderung meningkat dengan semakin tingginya puree wortel. Tabel 2 menunjukkan nilai kadar abu puree wortel sebesar $8,86 \%$ bk sedangkan kadar abu tepung singkong sebesar $0,88 \%$ bk. Hal ini disebabkan oleh kandungan gizi pada wortel kaya akan mineral seperti kalsium, kalium, fosfor, natrium dan besi (Astarina, 2010).

\section{Kadar Serat Kasar}

Hasil sidik ragam menunjukkan bahwa perbandingan tepung singkong dan puree wortel berpengaruh nyata $(p<0,05)$ terhadap kadar serat kasar kue stik. Tabel 3 menunjukkan nilai rata-rata kadar serat kasar pada kue stik perbandingan tepung singkong dan puree wortel berkisar antara 1,10\% 2,29\%. Nilai rata-rata kadar serat kasar terendah terdapat pada $\mathrm{P} 1$ yaitu $1,10 \%$ dan nilai rata-rata kadar serat kasar tertinggi terdapat pada P3 yaitu 2,29\%. Semakin banyak penambahan puree wortel cenderung membuat kadar serat kasar kue stik semakin meningkat. Hal ini disebabkan kadar serat kasar pada puree wortel lebih tinggi dibandingkan dengan kadar serat kasar tepung singkong. Tabel 2 menunjukkan nilai kadar serat kasar puree wortel sebesar $16,35 \%$ bk sedangkan kadar serat kasar tepung singkong sebesar $0,18 \%$ bk. Hasil tersebut sejalan dengan penelitian Sari dan Bahar (2014) tentang penelitian kue stik dengan substitusi mocaf $60 \%$ dan puree wortel $120 \%$ menghasilkan kadar serat sebesar 3,66\%.

\section{Kadar $\beta$-karoten}

Hasil sidik ragam menunjukkan bahwa perbandingan tepung singkong dan puree wortel berpengaruh nyata $(p<0,05)$ terhadap kadar betakaroten kue stik. Tabel 3 menunjukkan nilai rata-rata kadar betakaroten pada kue stik perbandingan tepung singkong dan puree wortel berkisar antara $3,27 \mathrm{mg} / 100 \mathrm{~g}-6,77 \mathrm{mg} / 100 \mathrm{~g}$. Nilai rata-rata kadar betakaroten terendah terdapat pada $\mathrm{P} 1$ yaitu $3,27 \mathrm{mg} / 100 \mathrm{~g}$ dan nilai ratarata kadar betakaroten tertinggi terdapat pada P3 yaitu $6,77 \mathrm{mg} / 100 \mathrm{~g}$. Hal ini disebabkan kadar betakaroten pada puree wortel lebih tinggi dibandingkan dengan kadar betakaroten tepung singkong. Tabel 2 menunjukkan nilai kadar betakaroten puree wortel sebesar $13,30 \mathrm{mg} / 100 \mathrm{~g}$ sedangkan kadar betakaroten tepung singkong sebesar $0,17 \mathrm{mg} / 100 \mathrm{~g}$. Jika dibandingkan dengan kadar betakaroten kue stik disetiap 
perlakuan mengalami penurunan dari kadar betakaroten puree wortel itu sendiri. Hal ini disebabkan karena betakaroten senyawa yang larut dalam lemak dan pengaruh suhu tinggi selama proses penggorengan kue stik membuat senyawa betakaroten rusak akibat proses oksidasi (Purwanti et al, 2019). Menurut Sari dan Bahar (2014) kue stik dengan substitusi mocaf $60 \%$ dan puree wortel $120 \%$ menghasilkan kadar betakaroten sebesar $81,60 \mathrm{mg} / 100 \mathrm{~g}$.

\section{Sifat Sensoris}

Evaluasi sifat sensoris kue stik perbandingan tepung singkong dan puree wortel dilakukan dengan uji hedonik terhadap warna, aroma, rasa, tekstur dan penerimaan keseluruhan. Nilai rata- rata uji hedonik terhadap warna, aroma, rasa, tekstur dan penerimaan keseluruhan kue stik dapat dilihat pada Tabel 4.

Tabel 4. Nilai rata-rata uji hedonik warna, aroma, rasa, tekstur dan penerimaan keseluruhan kue stik perbandingan tepung singkong dan puree wortel

\begin{tabular}{cccccc}
\hline Tepung & \multicolumn{5}{c}{ Nilai Rata-Rata Uji Hedonik } \\
$\begin{array}{c}\text { Singkong : } \\
\text { Puree } \\
\text { Wortel }\end{array}$ & Warna & Aroma & Rasa & Tekstur & $\begin{array}{c}\text { Penerimaan } \\
\text { Keseluruhan }\end{array}$ \\
\hline $\begin{array}{c}\text { P1(90\%: } \\
\text { 10\%) }\end{array}$ & 5,90 & 5,80 & 5,75 & 5,90 & 5,75 \\
P2(80\%: & 5,80 & 5,85 & 6,00 & 6,10 & 5,80 \\
$20 \%)$ & 5,90 & 6,00 & 6,05 & 6,00 & 6,10 \\
P3(70\%: & $50 \%)$ & & & & \\
$30 \%$
\end{tabular}

Keterangan: ( 7 = Sangat suka; 6 = Suka; 5 = Agak suka; 4 = Biasa; 3 = Agak tidak suka; 2 Tidak suka; 1 = Sangat tidak suka).Huruf yang sama dibelakang nilai rata-rata pada kolom yang sama menunjukkan berbeda tidak nyata $(\mathrm{P}>0,05)$.

\section{Warna}

Berdasarkan hasil sidik ragam, perlakuan perbandingan tepung singkong dan puree wortel berpengaruh tidak nyata $(p>0,05)$ terhadap kesukaan warna kue stik. Penerimaan terhadap warna kue stik perbandingan tepung singkong dan puree wortel adalah suka. Hal ini disebabkan perlakuan puree wortel hingga 30\% belum memberikan pengaruh terhadap tingkat kesukaan panelis pada warna kue stik.

\section{Aroma}

Berdasarkan hasil sidik ragam, perlakuan perbandingan tepung singkong dan puree wortel berpengaruh tidak nyata $(p>0,05)$ terhadap kesukaan aroma kue stik. Penerimaan terhadap aroma kue stik perbandingan tepung singkong dan puree wortel adalah suka. Hal ini disebabkan perlakuan puree wortel hingga $30 \%$ belum memberikan pengaruh terhadap tingkat kesukaan panelis pada aroma kue stik. 


\section{Rasa}

Berdasarkan hasil sidik ragam, perbandingan tepung singkong dan puree wortel berpengaruh tidak nyata $(p>0,05)$ terhadap kesukaan rasa kue stik. Penerimaan terhadap rasa kue stik perbandingan tepung singkong dan puree wortel adalah suka. Hal ini disebabkan perlakuan puree wortel hingga $30 \%$ belum memberikan pengaruh terhadap tingkat kesukaan panelis pada rasa kue stik.

\section{Tekstur}

Berdasarkan hasil sidik ragam, perlakuan perbandingan tepung singkong dan puree wortel berpengaruh tidak nyata $(p>0,05)$ terhadap kesukaan tekstur kue stik. Penerimaan terhadap tekstur kue stik perbandingan tepung singkong dan puree wortel adalah suka. Hal ini disebabkan perlakuan puree wortel hingga 30\% belum memberikan pengaruh terhadap tingkat kesukaan panelis pada tekstur kue stik.

\section{Penerimaan Keseluruhan}

Berdasarkan hasil sidik ragam, perlakuan perbandingan tepung singkong dan puree wortel berpengaruh tidak nyata $(p>0,05)$ terhadap penerimaan keseluruhan kue stik. Penerimaan keseluruhan terhadap kue stik perbandingan tepung singkong dan puree wortel adalah suka. Secara keseluruhan panelis dapat menerima perlakuan perbandingan tepung singkong dan puree wortel dalam mengolah kue stik. Selain itu faktor yang mempengaruhi penerimaan keseluruhan terhadap suatu produk adalah warna, aroma, rasa dan tekstur.

\section{KESIMPULAN DAN SARAN}

\section{Kesimpulan}

Berdasarkan hasil penelitian yang telah dilakukan dapat diambil kesimpulan bahwa perlakuan perbandingan tepung singkong dan puree wortel berpengaruh terhadap kadar air, kadar abu, kadar serat kasar dan kadar betakaroten. Perbandingan $70 \%$ tepung singkong : $30 \%$ puree wortel dapat menghasilkan kue stik dengan karakteristik terbaik dan memiliki kriteria kadar air 2,00\%, kadar abu 2,01\%, kadar serat kasar 2,20\% dan kadar beta karoten $6,67 \mathrm{mg} / 100 \mathrm{~g}$. Hasil uji hedonik (warna, aroma, rasa, tekstur dan penerimaan keseluruhan) adalah suka. Kue stik dengan perbandingan tepung singkong dan puree wortel mempunyai kandungan gizi serat kasar dan betakaroten sehingga memiliki potensi sebagai pangan fungsional.

\section{Saran}

Membuat kue stik dengan penambahan tepung singkong dan puree wortel sebaiknya menggunakan perbandingan $70 \%$ tepung singkong dan $30 \%$ puree wortel.

\section{DAFTAR PUSTAKA}

Anonimus. 1992. Badan Standar Nasional Indonesia. Standar Mutu Kue Kering (Biskuit) (SNI 01-2973-1992). BSN. Jakarta. 
Anonimus. 2018. APTINDO. Industri tepung terigu nasional. http://aptindo.or.id/201 6/10/26/industri-tepung-terigunasional/. Diakses 5 Agustus 2019.

Association of Official Analytical Chemist (AOAC). 2006. Official Methods of AOAC International. Revisi ke-2. Vol ke-1. Maryland (US): Association of Official Analytical Chemist.

Apriyantono, A. 1989. Analisis Pangan. PAU Pangan dan Gizi. Institut Pertanian Bogor, Bogor.

Astarina. 2010. Pengaruh substitusi tepung wortel pada pembuatan kue stik ditinjau dari kadar betakaroten, sifat organoleptik dan daya terima. Skripsi. Program Studi S1 Gizi. Fakultas Ilmu Kesehatan, Universitas Muhammadiyah Surakarta. Surakarta.

Gomez, K. A. dan A. A. Gomez. 1995. Prosedur Statistik Untuk Penelitian Pertanian. UI Press, Jakarta.

Habeahan, Y. M. 2018. Pemanfaatan tepung ubi jalar orange dan tepung kelor sebagai subtitusi tepung terigu pada pembuatan stick kue bawang, kandungan gizi, dan daya terimanya. Fakultas Ilmu Kesehatan, Univsersitas Sumatera Utara, Medan.

Koswara. 2009. Teknologi Modifikasi Pati. eBook Pangan.com. Diakses 11 Juli 2019.
Purwanti, R., R. Fadillah dan S.Yanto. 2019. Pengaruh metode dan lama pengolahan terhadap analisis mutu ubi jalar orange (Ipomoea batatas L). Program Studi Pendidikan Teknologi Pertanian, Fakultas Teknik, Universitas Negeri Malang, Malang.

Salim, A. 2011. Mengolah Tepung Singkong Menjadi Tepung Mocaf. Lily Publisher. Yogyakarta.

Sari, J. M. dan A. Bahar. 2014. Pengaruh subtitusi tepung mocaf (modified cassava flour) dan penambahan puree wortel (Daucus carota L) terhadap sifat organoleptik stick. Fakultas Teknik, Universitas Negeri Surabaya. Surabaya.

Soekarto, S.T. 1985. Penilaian Organoleptik Untuk Industri Pangan dan Pertanian. Bharata Karya Aksara. Jakarta.

Widowati, S. dan D. S. Damardjati. 2001. Menggali Sumberdaya Pangan Lokal dan Peran Teknologi Pangan Dalam Rangka Ketahanan Pangan Nasional. Majalah Pangan. 6:3-11.

Yanuarti, A.R dan M. D. Afsari. 2016. Profil komoditas barang kebutuhan pokok dan barang penting: komoditas tepung terigu.

https://ews.kemendag.go.id/download. aspx?fle=BK_TERIGU. Diakses pada tanggal 16 Agustus 2018. 